\title{
Barriers to contraceptives use among women in a low resource setting in Enugu, south east Nigeria
}

\author{
Onyinye Chiamaka Ezugwu, ${ }^{1}$ Euzebus Chinonye Ezugwu, ${ }^{2,3}$ Bridget Obioma Mbah, ${ }^{4}$ \\ Chinwe Victoria Ukwe ${ }^{5}$
}

${ }^{1}$ Department of Pharmacy, Enugu State University of Science and Technology; ${ }^{2}$ Department of Obstetrics and Gynaecology, College of Medicine, University of Nigeria Ituku-Ozalla, Enugu state; ${ }^{3}$ Department of Obstetrics and Gynaecology, University of Nigeria Teaching Hospital, Ituku-Ozalla Campus, Enugu State; ${ }^{4}$ Department of Home Science, Nutrition and Dietetics, University of Nigeria, Nsukka; ${ }^{5}$ Department of Clinical Pharmacy and Pharmacy management, University of Nigeria, Nsukka, Nigeria

\begin{abstract}
Objective of the study: The study was aimed to determine barriers to modern contraceptive use among pregnant women attending antenatal care at Enugu State University Teaching Hospital from $1^{\text {st }}$ March to $31^{\text {st }}$ May 2014.

Materials and Methods: Using a semi-structured questionnaire, relevant data were extracted. Data were entered and analyzed using Epi Info ${ }^{\mathrm{TM}}$ statistical software version 7. p value $<0.05$ was considered statistically significant.

Results: A total of 432 women participated in the study. Their
\end{abstract}

mean age was $28.6 \pm 4.4$ years. The majority were married (93.06\%), multiparous (59\%) and mainly Igbos (93.06\%). Although the level of awareness of modern contraceptive among the respondents was high $(91.8 \%)$, only about $35 \%$ of them $(n=151 / 432)$ had ever used modern contraceptives in the past. Over one-third $(36.3 \%, n=144 / 397)$ of the respondents who were aware of modern contraceptive do not intend to ever use modern contraceptive in future. The self-reported barriers to the use of modern contraceptive were; religious barrier (53.9\%), fear of side effect (24\%), husband's disapproval (17.8\%) and cost.

Conclusions: Addressing these identified barriers hopefully will promote the use of modern contraceptive for family planning thus preventing unintended pregnancy in our sub region

\section{Introduction}

It is estimated that Nigeria has a population of about 190 million, with annual population growth rate of $2.7 \%{ }^{1}$ Nigeria is the most populous nation in Africa and the $6^{\text {th }}$ most populous nation in the world. It is estimated that Nigeria population is about 208 million. ${ }^{2}$ The rapid population growth have been attributed to lack of education, religion, male child preference, high infant mortality and high unmet need for contraceptives. ${ }^{3}$

Although Nigeria has a high total fertility rate of 5.7, about $18 \%$ of married women do not desire future child bearing while one-third of married women in Nigeria want to wait at least two years before their next birth. ${ }^{4}$ Unfortunately, not all married women in Nigeria can freely access modern contraceptive for family planning. Nigeria has unmet need for family planning among married women of about $16 \%{ }^{4}$

The high unmet need for contraception in the sub-Saharan African region significantly contributes to the reportedly high prevalence rate of unintended pregnancy in the region. It has been reported that if unmet need for contraception are satisfied in sub Saharan Africa, unintended pregnancy would drop by $83 \%$, from 18 million to 3 million per year and unsafe abortions would decline by $84 \%$, from 5.7 million to 0.9 million. $^{5}$

Modern contraceptives are very effective in preventing unintended and/or unwanted pregnancy and its attendant complications. Unintended and unwanted pregnancies are known risk factors for pregnancy termination. In countries with restrictive abortion law like in Nigeria, abortion services by skilled personnel and in standard health facilities are not readily available for women. This makes the procurement of pregnancy termination an act done secretly, with quacks cashing in the gap in service delivery with resultant high complication and even death in some cases. ${ }^{6}$ 
Millions of women lose their lives annually especially in the developing world while attempting to abort an unintended and unwanted pregnancy. ${ }^{6}$ Unsafe abortion is one of the five leading causes of maternal deaths in Nigeria. ${ }^{7}$ The role of modern contraceptives in maternal mortality reduction and for population control in Nigeria and in many countries in the sub region cannot be overemphasized. Understanding the level of awareness and self-reported barrier to the use of modern contraceptives among women in Enugu, south east Nigeria will be of great help to policy makers, reproductive health experts at the federal, state and local level and other governmental and non-governmental agencies in their strategic planning towards improving the reproductive health needs of women in the region. The study was aimed to determine the level of awareness, the practice and barriers to the use of modern contraceptives among pregnant women receiving antenatal care at Enugu State University of Science and Technology Teaching Hospital (ESUTH), Enugu Nigeria.

\section{Materials and Methods}

In a questionnaire-based cross-sectional study, the level of awareness, the practice and barriers to the use of modern contraceptives were assessed among pregnant women receiving antenatal care at ESUTH from the $1^{\text {st }}$ March to $31^{\text {st }}$ May 2014. ESUTH is a tertiary health institution located in Enugu, a metropolitan city and the capital of Enugu State, south east Nigeria. ESUTH provides health services to the people of Enugu State and other neighboring states of Ebonyi, Anambra, Imo, Abia, and some parts of Benue State. It is the only government-owned tertiary hospital located within the city center offering obstetric and gynaecological services. It also offers both primary and secondary level of health care.

Prior to commencement of the study, ethical approval was obtained from the Institutional Ethics Committee. Based on contraceptive prevalence rate of $29 \%$ earlier reported among married women in south east Nigeria, ${ }^{4}$ it was calculated that 450 study participants would be adequate for the study. Therefore, 450 study participants were consecutively recruited from the antenatal care unit of the hospital. Using a pretested questionnaire, trained medical interns conducted a face-to-face interview with the participants to obtain the following information: respondent's age, education level, occupation, parity, knowledge about contraceptive methods, source of information, previous and current use of family planning methods and possible barriers to contraceptive use. The questionnaires were cross-checked to ensure completeness.

Data were entered and analyzed by using Epi Info statistical software version 17 (Centers for Disease Control and Prevention, Atlanta, GA, USA). Frequency tables were generated for relevant variables. Proportions were compared via Pearson $\chi^{2}$ test or Fisher exact test as appropriate, and relationships were expressed via the Odds Ratio (OR) and Confidence Interval (CI).

\section{Results}

Of the 450 questionnaire administered, 432 (96\%) were analyzed while $18(4 \%)$ of them were excluded due to incomplete data. The mean age of the participants was 28.6 \pm 4.4 years (range $=16-45$ years). The majority of them were aged $20-39$ years (97\%), married (93.06\%), multiparous (59\%), Igbos (93.06\%), with some level of education. They were mainly Christians $(97.2 \%)$ and reside mainly in the urban area (56.9\%). The details are shown in Table 1.

The majority of the respondents $(91.8 \%, n=397 / 432)$ were aware of modern contraceptives. About $46.4 \%$ reported being aware of more than 3 different types of modern contraceptives. The male condom was the commonest method known to the respondent (91.7\%, $\mathrm{n}=364 / 397)$, while the female condom was the least known method $(5.2 \%, n=22 / 397)$. The source of their information about modern contraception were: hospital (40.3\%), health talks $(21.2 \%)$, friends and relatives $(13.4 \%)$, radio and television $(10.8 \%)$ etc. One-fifth $(n=86 / 432)$ of the respondents did not know that there was a family planning unit at the study center. The details are shown in Table 2.

More than one third of the respondents $(36.3 \%, n=144 / 397)$ that were aware of modern contraceptive do not intend to ever use modern contraceptive in future, while another $18.9 \%(n=75 / 397)$ were undecided. The reasons adduced by these respondents for not being willing to use modern contraceptives include: religious barrier $(53.9 \%)$, fear of side effect $(25.1 \%)$, husband's disapproval (17.8\%) and cost barrier (3.2\%). About a half (51.9\%, $n=206 / 397)$ of the respondents who were aware of modern contraceptive were either undecided or would not recommend modern contraceptives to a friend or relative. The details are shown in Table 2.

Table 1. Socio-demographic characteristics of the respondents.

\begin{tabular}{|c|c|c|}
\hline Characteristics & $\begin{array}{l}\text { No of respondents } \\
\qquad(\mathrm{n}=432)\end{array}$ & $\begin{array}{c}\text { Percentage } \\
\text { (\%) }\end{array}$ \\
\hline $\begin{array}{l}\text { Age (years) } \\
\quad \leq 19 \\
20-29 \\
30-39 \\
\geq 40\end{array}$ & $\begin{array}{c}5 \\
252 \\
167 \\
7\end{array}$ & $\begin{array}{c}1.26 \\
58.36 \\
38.8 \\
1.58\end{array}$ \\
\hline $\begin{array}{l}\text { Parity } \\
\text { Nulliparous } \\
\text { Multiparous } \\
\end{array}$ & $\begin{array}{l}176 \\
256\end{array}$ & $\begin{array}{l}40.7 \\
59.3\end{array}$ \\
\hline $\begin{array}{l}\text { Marital status } \\
\text { Single } \\
\text { Married } \\
\text { Divorced } \\
\text { Widow }\end{array}$ & $\begin{array}{c}16 \\
402 \\
11 \\
3\end{array}$ & $\begin{array}{c}3.79 \\
93.06 \\
2.52 \\
0.63\end{array}$ \\
\hline $\begin{array}{l}\text { Highest educational level attained } \\
\text { Primary } \\
\text { Secondary } \\
\text { Tertiary }\end{array}$ & $\begin{array}{l}29 \\
274 \\
129\end{array}$ & $\begin{array}{l}6.8 \\
63.4 \\
29.8\end{array}$ \\
\hline $\begin{array}{l}\text { Religion } \\
\text { Christians } \\
\text { Moslem }\end{array}$ & $\begin{array}{c}420 \\
12\end{array}$ & $\begin{array}{l}97.2 \\
2.8\end{array}$ \\
\hline $\begin{array}{l}\text { Christian denomination }(\mathrm{n}=420) \\
\text { Roman catholic } \\
\text { Anglican } \\
\text { Pentecostal } \\
\text { Orthodox }\end{array}$ & $\begin{array}{l}215 \\
106 \\
84 \\
15\end{array}$ & $\begin{array}{c}51.2 \\
25.2 \\
20 \\
3.6\end{array}$ \\
\hline $\begin{array}{l}\text { Occupation } \\
\text { House wife } \\
\text { Civil servant } \\
\text { Student } \\
\text { Applicant } \\
\text { Trader/ Business }\end{array}$ & $\begin{array}{c}60 \\
112 \\
136 \\
42 \\
82\end{array}$ & $\begin{array}{c}13.88 \\
25.87 \\
31.55 \\
9.78 \\
18.93\end{array}$ \\
\hline $\begin{array}{l}\text { Tribe } \\
\text { Igbo } \\
\text { Yoruba } \\
\text { Hausa } \\
\text { Others }\end{array}$ & $\begin{array}{c}402 \\
5 \\
8 \\
17\end{array}$ & $\begin{array}{l}93.06 \\
1.26 \\
1.89 \\
3.79\end{array}$ \\
\hline
\end{tabular}


Only about $35 \%$ of the respondents $(n=151 / 432)$ had ever used modern contraceptives in the past. The male condom was the commonest modern contraceptive ever used by the partner. But among the contraceptive used by the female gender, the injectables were the most commonly used $(51 \%, n=77 / 151)$, followed by IUCDs $(27.8 \%, n=42 / 151)$ and then pills $(13.2 \%, n=20 / 151)$. None of the respondents had ever used the female condom. The majority $(45 \%)$ of the users got their contraceptives from hospitals. The details are shown in Table 3.

There was a statistically significant relation between parity and ever use of modern contraception. A significantly higher number of multiparous respondents reported having ever used modern contraception in the past compared to the nulliparous respondents. The uptake of modern contraceptive was almost three times higher among multiparous women compared to nulliparous respondents. (43.36\% vs $22.73 \%$, OR=2.60, CI 1.69-4.00, p value $<0.01)$. However, marital status, educational status and religion of the respondent did not seem to affect the ever use of modern contraceptives. The details are shown in Table 4.

\section{Discussion}

The level of awareness of modern contraceptives among women attending antenatal care at ESUTH is high (91.8\%). This is higher than the national average of $85 \%$ reported among women in Nigeria. ${ }^{4}$ It is however similar to $90.3 \%$ reported among women in an inner city area of Osogbo, South west Nigeria. ${ }^{8}$ High level of contraceptive awareness were also reported in some centers in Tanzania, Ghana, Kenya and many other parts of Africa. ${ }^{9-13}$

The male condom was the commonest method of modern contraceptive known to the respondents, unlike what was reported in the 2013 Nigerian National demographic Health Survey (NDHS) where oral pill was the commonest known contraceptive method among women in Nigeria. ${ }^{4}$ Our finding is similar to that reported in Osogbo, Nigeria. ${ }^{8,14}$ Surprisingly, the female condom was the least known method among the respondent. The female condom remains the only method that is fully under the control of the woman, yet the least known by women. It is possible that the relative scarcity and non-availability of female condom in most health facility in the study area may have contributed to the low level of awareness recorded. Although majority of the respondents $(80 \%)$ were aware of 3 or more different types of modern contraceptives, the level of awareness to long acting reversible contraceptives such as the intrauterine contraceptive devise and implants still remains low. Creating awareness on the different methods of modern contraceptives available will help women make an informed decision on which method of modern contraceptive to use.

Surprisingly, despite the high level of awareness among the study group, only about one-third of the respondents $(35 \%)$ had ever used modern contraceptives. This finding is similar to that reported in the 2013 Nigeria National demographic health survey, where despite the high level of awareness $(85 \%)$ of modern contraceptives among married women, only $15 \%$ of currently married women had ever used any modern contraceptive. ${ }^{4}$ The high level of awareness and poor utilization pattern among respondents have been previously reported in many African countries. ${ }^{8-13,15-18}$

The most commonly used contraceptive among those that had ever used modern contraceptive was the male condom. This is similar to that reported in Osogbo and Lagos both in Nigeria. ${ }^{8,14}$ Male condoms are readily available, accessible, cheap and easy to use. These may have accounted for its high usage. Male condom has an additional beneficial effect as a barrier contraceptive. It offers dual
Table 2. Distribution of respondents based on their awareness and attitude towards modern contraception.

\begin{tabular}{|c|c|c|}
\hline Variable & $\begin{array}{c}\text { Frequency } \\
(\mathrm{n}=432)\end{array}$ & $\begin{array}{c}\text { Percent } \\
(\%)\end{array}$ \\
\hline $\begin{array}{l}\text { Aware of modern contraception } \\
\text { Aware } \\
\text { Not aware }\end{array}$ & $\begin{array}{c}397 \\
35\end{array}$ & $\begin{array}{l}91.8 \\
8.2\end{array}$ \\
\hline $\begin{array}{l}\text { No. of modern contraceptive methods known (n } \\
1 \\
2 \\
3 \\
\text { More than } 3\end{array}$ & $\begin{array}{c}18 \\
40 \\
159 \\
180\end{array}$ & $\begin{array}{c}4.5 \\
10.1 \\
40.1 \\
45.3\end{array}$ \\
\hline $\begin{array}{l}\text { Type of modern contraceptive known* }(\mathrm{n}=397) \\
\text { Male condom } \\
\text { Pills } \\
\text { Injectables } \\
\text { IUDs } \\
\text { Implants } \\
\text { Bilateral tubal ligation } \\
\text { Female condom }\end{array}$ & $\begin{array}{l}364 \\
357 \\
266 \\
202 \\
143 \\
60 \\
20\end{array}$ & $\begin{array}{l}91.7 \\
89.9 \\
67.0 \\
50.9 \\
36.0 \\
15.1 \\
5.2\end{array}$ \\
\hline $\begin{array}{l}\text { Source of information ( } \mathrm{n}=397) \\
\text { Hospital } \\
\text { Health talk } \\
\text { Friends/relatives } \\
\text { Radio/television } \\
\text { School } \\
\text { Newspaper/magazine }\end{array}$ & $\begin{array}{l}160 \\
84 \\
53 \\
40 \\
40 \\
17\end{array}$ & $\begin{array}{l}40.3 \\
21.2 \\
13.4 \\
10.1 \\
10.1 \\
4.3\end{array}$ \\
\hline $\begin{array}{l}\text { Is family planning facility in ESUTH? }(\mathrm{n}=432) \\
\text { Yes } \\
\text { No } \\
\text { I don't know }\end{array}$ & $\begin{array}{c}346 \\
60 \\
26\end{array}$ & $\begin{array}{l}80 \\
14 \\
6\end{array}$ \\
\hline $\begin{array}{l}\text { Do you intend to ever use modern contraceptio } \\
\text { for family planning in the future? ( } \mathrm{n}=397 \text {; those } \\
\text { Yes } \\
\text { No } \\
\text { Undecided }\end{array}$ & $\begin{array}{l}178 \\
144 \\
75\end{array}$ & $\begin{array}{l}44.8 \\
36.3 \\
18.9\end{array}$ \\
\hline $\begin{array}{l}\text { If No or undecided, state why? }(\mathrm{n}=219) \\
\text { Disapproval based on religious sentiments } \\
\text { Fear of side effect } \\
\text { Husband's disapproval } \\
\text { Cost implication }\end{array}$ & $\begin{array}{c}118 \\
55 \\
39 \\
7\end{array}$ & $\begin{array}{c}53.9 \% \\
25.1 \\
17.8 \\
3.2\end{array}$ \\
\hline $\begin{array}{l}\text { Would you recommend modern contraceptives } \\
\text { to your friend or relatives? }(\mathrm{n}=397) \\
\text { Yes } \\
\text { No } \\
\text { Undecided }\end{array}$ & $\begin{array}{c}191 \\
119 \\
87\end{array}$ & $\begin{array}{c}48.1 \\
30 \\
21.9\end{array}$ \\
\hline
\end{tabular}

*Data was based on multiple responses.

Table 3. Distribution of the respondents based on ever used contraception in the past.

$\begin{array}{lcc}\text { Variable } & \text { Frequency Percent } \\ \text { Have you ever used modern contraception } & & \\ \quad \text { in the past? (n=432) } & 151 & 35.0 \\ \quad \text { Yes } & 281 & 65.0 \\ \quad \text { No } & 139 & 92.0 \\ \text { Modern contraceptives ever used? }(\mathrm{n}=151)^{* *} & 77 & 51.0 \\ \quad \text { Male condom (partner) } & 42 & 27.8 \\ \text { Injectables } & 20 & 13.2 \\ \text { IUCD } & 12 & 8.0 \\ \text { Pills } & & \\ \text { Implants } & 68 & 45.0 \\ \text { Source of the contraceptives used? } & 60 & 39.8 \\ \text { Hospital } & 23 & 15.2 \\ \quad \text { Health centers } & & \end{array}$


protection. The male and female condom when used properly can prevent unwanted pregnancy and sexually transmitted diseases. The promotion of the use of barrier contraceptive with the advent of HIV infection may have also contributed to the high usage of the male condom. This is not the case with female condom, as none of the respondents in the study had ever used a female condom. Surprisingly, even among HIV positive women in Enugu, a recent report showed that none of them ever used the female condom. ${ }^{19}$ Female condom offer dual protection with an added advantage of being under the control of the woman. Regrettably, it is scarce and hardly available in most centers in Nigeria.

Injectables were the second most commonly used contraceptive from the study. It is a convenient method of contraception in a society like ours where women are denied the right to modern contraceptives. ${ }^{20}$ Women who do not want their husband to know that they are on contraceptive could secretly go to the health center and get injected without their husband's knowledge. It is worrisome to note that over one third of the respondents who were aware of modern contraception indicated that they will never use modern contraceptive in the future. Another $18.9 \%$ of them were undecided. The identified barriers to the use of modern contraceptives as reported by the respondents were: respondent's disapproval based on religious inclination, fear of side effects, husband's disapproval and cost limitations.

Many of the Christians respondents, who were of the Roman Catholic denomination, indicated that the use of modern contraception was against the doctrine of their church. Most Roman Catholics faithful's generally prefer natural family planning: abstinence, withdrawal method and avoiding intercourse during the time of ovulation. Natural family planning methods are associated with higher failure rate compared with modern contraception. Natural family planning methods require a lot of discipline and self-control from the couple that may not be guaranteed at all times. The associated high failure rate may put the couple at risk of unintended and unwanted pregnancy and its attendant complication. Previous studies have reported fear of side effect, myths and misconceptions about modern contraception as a major barrier to the use of modern contraception ${ }^{8,21-23}$ as seen in this study. Such fears are usually unfounded. This finding buttresses the need for education and re-education of women in the reproductive age group to correct such misconceptions and alleviate their fears.
Another identified barrier was the husband/partner's disapproval to the use of modern contraceptives. Husband/partner's disapproval as a barrier to the use of modern contraceptives have been reported by previous studies. $6,18,20,21$ Due to our culture of male dominance, most women are denied of their right to use modern contraceptives. ${ }^{20}$ Interesting, more than half of the respondents reported that the final decision on fertility (i.e. when to have the next birth and the number of children a couple should have) rests on the man. This suggests that involving men in contraceptive and other reproductive health issues may improve uptake of modern contraception among women in Nigeria and in many developing countries.

A few of the respondent reported cost as a barrier to the use of modern contraceptive of their choice. They claim that contraceptive implants (Jadelle) and levo-norgestrel impregnated intra uterine contraceptive devices when available are too expensive and unaffordable. This emphasizes the need for government and nongovernmental agencies to subsidize its cost and ensure its availability at the family planning clinics to encourage uptake.

Shockingly, a significant number of the respondents were unaware of the presence of a family planning unit in the study center. This suggests that it is not just enough to have a family planning unit in a hospital. The hospital authority should adopt strategies to create awareness of the existence of such facility/services so that whosoever desires, may avail him or herself of the services.

The study has some limitations. The study was hospital based and may not reflect the true situation in the general population. Secondly, the study was conducted in one center only. A multi-centered study involving many hospitals in Enugu may be a better representation of women in Enugu. However, despite these limitations the finding of this study may be very useful in policy making by the relevant authorities and agencies.

In conclusion, the level of utilization of modern contraceptives is not commensurate to the high level of awareness to modern contraceptives recorded in the study centre. Fear of side effects, respondent's disapproval due to religious inclination, partner's disapproval and cost were the identified major barrier to modern contraceptive use. There should be concerted effort to address these issues raised to ensure increased contraceptive uptake. This hopefully will reduce the rate of unintended and unwanted pregnancy and its attendant complications in our region.

Table 4. Association between respondents' demographic/reproductive characteristics and uptake of contraception

\begin{tabular}{|c|c|c|c|c|c|}
\hline Variables & $\begin{array}{l}\text { Con } \\
\text { Yes }(\%)\end{array}$ & $\begin{array}{l}\text { sed } \\
\text { No }(\%)\end{array}$ & Total $(n=432)$ & OR $(95 \% \mathrm{CI})$ & P value \\
\hline Marital status & & & & & \\
\hline Single & $5(31.25)$ & 11(68.75) & $16(3.7)$ & $0.84(0.29-2.47)$ & 0.8 \\
\hline Ever married & $146(35.1)$ & $270(64.9)$ & $416(96.3)$ & & \\
\hline $\begin{array}{l}\text { No. of living children } \\
\text { Multiparty } \\
\text { Nulliparity }\end{array}$ & $\begin{array}{c}111(43.36) \\
40(22.73)\end{array}$ & $\begin{array}{l}145(56.64) \\
136(77.27)\end{array}$ & $\begin{array}{l}256(59.3) \\
176(40.7)\end{array}$ & $2.60(1.69-4.00)$ & $<0.001$ \\
\hline $\begin{array}{l}\text { Educational level } \\
\text { Primary } \\
\text { Post primary }\end{array}$ & $\begin{array}{c}8(27.59) \\
143(35.48)\end{array}$ & $\begin{array}{c}21(72.41) \\
260(64.52)\end{array}$ & $\begin{array}{c}29(6.7) \\
403(93.3)\end{array}$ & $0.69(0.30-1.6)$ & 0.39 \\
\hline $\begin{array}{l}\text { Religion } \\
\text { Christianity } \\
\text { Islam }\end{array}$ & $\begin{array}{c}149(35.48) \\
2(16.67)\end{array}$ & $\begin{array}{c}271(64.52) \\
10(83.33)\end{array}$ & $\begin{array}{c}420(97.2) \\
12(2.8)\end{array}$ & $2.75(059-12.71)$ & 0.20 \\
\hline
\end{tabular}




\section{References}

1. World Bank Group, Nigeria | Data. Accessed 28 May 2019. Available from: http://data.worldbank.org/country/nigeria

2. National Population Commission, Data for national development, Nigeria. Accessed December 2020. Available form: https://www.worldometers.info/world-population/nigeria-population/

3. Oramah TI. The effects of population growth in Nigeria. J Appl Sci 2006;6:1332-7.

4. Nigeria Demographic and Health Survey. National Demographic and Health Survey for Nigeria. 2013. Available from: https://dhsprogram.com/pubs/pdf/fr293/fr293.pdf

5. United Nations Population Fund. Fact sheet; Investing in Sexual and Reproductive Health in Sub-Saharan Africa. 2014. Accessed July 13, 2015. Available from: http://www.unfpa. org/resources/adding-it-2014-sub-saharan-africa-fact-sheet

6. Adinma E. Unsafe abortion and its ethical, sexual and reproductive rights implications. West Afr J Med 2011;30:245-9.

7. Ezugwu EC, Agu PU, Nwoke MO, Ezugwu FO. Reducing maternal deaths in a low resource setting in Nigeria. Niger $\mathrm{J}$ Clin Pract 2014;17:62-6.

8. Asekun-Olarinmoye EO, Adebimpe WO, Bamidele JO, et al. Barriers to use of modern contraceptives among women in an inner city area of Osogbo metropolis, Osun State, Nigeria. Int J Womens Health 2013;5:647-55.

9. Lwelamira J, Mnyamagola G, Msaki M. Knowledge, Attitude and Practice (KAP) towards modern contraceptives among married women of reproductive Age in Mpwapwa District, Central Tanzania. Curr Res J Soc Sci 2012;4:235-45.

10. Aryeetey R, Kotoh AM, Hindin MJ. Knowledge, perceptions and ever use of modern contraception among women in the Ga East District, Ghana. Afr J Reprod Health 2010;14:26-31.

11. Mathe JK, Kasonia KK, Maliro AK. Barriers to adoption of family planning among women in Eastern Democratic Republic of Congo. Afr J Reprod Health 2011;15:69-77.

12. Opoku B, Kwaununu F. Knowledge and practices of emergency contraception among Ghanaian women. Afr J Reprod
Health 2011;15:147-52

13. Ochako R, Mbondo M, Aloo S, et al. Barriers to modern contraceptive methods uptake among young women in Kenya: a qualitative study. BMC Public Health 2015;15:1-9.

14. Oye-Adeniran BA, Adewole IF, Odeyemi KA, et al. Contraceptive prevalence among young women in Nigeria. J Obstet Gynaecol 2005;25:182-5.

15. Arowojolu AO, Ilesanmi AO, Roberts OA, Okunola MA. Sexuality, contraceptive choice and AIDS awareness among Nigerian undergraduates. Afr J Reprod Health 2002;6:60-70

16. Rutstein S. Further evidence of the effects of preceding birth intervals on neonatal, infant and under-five-year mortality and nutritional status in developing countries: evidence from the demographic and health surveys. DHS Working Paper No. 41. Int J Gynaecol Obstet 2008:S7-S24 p

17. Conde-Agudelo A, Belizán JM. Maternal morbidity and mortality associated with interpregnancy interval: cross sectional study. BMJ 2000;321:1255-9.

18. Gillespie DG. Whatever happened to family planning, and, for that matter, reproductive health? Int Fam Plan Perspect 2004;30:34-8.

19. Ezugwu EC, Nkwo PO, Agu PU, et al. Contraceptive use among HIV-positive women in Enugu, southeast Nigeria. Int J Gynecol Obstet 2014;126:14-7

20. Chigbu CO, Onyebuchi AK, Onwudiwe EN, Iwuji SE. Denial of women's rights to contraception in southeastern Nigeria. Int J Gynecol Obstet 2013;121:154-6.

21. Randrianasolo B, Swezey T, Van Damme K, et al. Barriers to the use of modern contraceptives and implications for womancontrolled prevention of sexually transmitted infections in Madagascar. J Biosoc Sci 2008;40:879-93

22. Casterline JB, Sinding SW. Unmet need for family planning in developing countries and implications for population policy. Popul Dev Rev 2000;26:691-723.

23. Nagase T, Kunii O, Wakai S, Khaleel A. Obstacles to modern contraceptive use among married women in southern urban Maldives. Contraception 2003;68:125-34. 